\title{
PENGARUH PROGRAM KELUARGA HARAPAN (PKH) TERHADAP PARTISIPASI PENDIDIKAN DI KECAMATAN INDRAJAYA KABUPATEN PIDIE
}

\author{
R U S Y D I \\ Dosen pada Politeknik Negeri Lhokseumawe, Lhokseumawe
}

The purpose of this research is to know the influence of Program Keluarga Harapan Aid (PKH) to Education Participation in Indrajaya Sub-district of Pidie Regency. The population in this study were all household heads receiving PKH assistance in Indrajaya sub-district, Aceh Pidie district. Sampling was done randomly by using "stratisfield random sampling" method as much as 10 percent from 409 respondents to get 41 respondents. The results showed PKH grant funds provided to increase education participation in Indrajaya Sub-district PKH Assistance was able to explain or influence the education participation of KSM children in Indrajya Kabupaten Pidie reached 96.8 percent and the rest of 3.2 percent influenced by other variables outside the model this research. The provision of PKH assistance should be well targeted and truly aimed at improving children's education. This is important, as such assistance is only temporary and more focused on deciding the poverty chain.

Keywords: Program Keluarga Harapan Aid (PKH), Education Participation 


\section{LATAR BELAKANG}

PKH (Program Keluarga Harapan) merupakan salah satu Program Pemerintah dalam rangka percepatan penanggulangan kemiskinan sekaligus pengembangan kebijakan di bidang perlindungan sosial, PKH sudah dilaksanakan di Indonesia sejak tahun 2007. Program ini lebih dikenal dengan istilah Conditional Cash Transfer (CCT) atau bantuan tunai bersyarat. Dalam PKH, bantuan akan diberikan kepada Rumah Tangga Sangat Miskin (RTSM) yang kategorinya sudah ditentukan oleh Badan Pusat Statistik (BPS) dan sebagai imbalannya RTSM tersebut diwajibkan untuk menyekolahkan anaknya. Rendahnya penghasilan keluarga sangat miskin menyebabkan keluarga tersebut tidak mampu memenuhi kebutuhan pendidikan untuk tingkat minimal sekalipun. Alasan terbesar untuk tidak melanjutkan sekolah ialah karena tidak ada biaya, bekerja untuk mencari nafkah, merasa pendidikannya sudah cukup dan berbagai alasan lainnya. Maka dengan itu PKH merupakan cikal bakal pengembangan sistem perlindungan sosial, khususnya bagi keluarga miskin, dengan tujuan akhir PKH adalah meningkatkan partisipasi sekolah baik itu sekolah dasar maupun sekolah menengah. Untuk meningkatkan partisipasi sekolah $\mathrm{PKH}$ harus dapat menjaring mereka yang berada di luar sistem persekolahan termasuk mereka yang menjadi pekerja anak, terutama untuk daerah yang diduga banyak terdapat pekerja anaknya akan dibekali dengan pengetahuan berkaitan dengan bimbingan kepada pekerja anak dalam rangka mempersiapkan mereka kembali ke bangku sekolah. Komponen pendidikan dasar wajib 9 tahun serta upaya mengurangi angka pekerja anak pada keluarga yang sangat miskin. Anak penerima PKH pendidikan yang berusia 7-18 tahun belum menyelesaikan program pendidikan dasar 9 tahun harus mendaftarkan diri disekolah formal atau non formal serta hadir sekurang - kurangnya $85 \%$ waktu tatap muka. Setiap anak peserta $\mathrm{PKH}$ berhak menerima bantuan selain PKH, baik itu Program Nasioanal maupun lokal. Dengan demikian PKH membuka peluang terjadinya sinergi antara program yang mengintervensi sisi supply (pelayanan) dan demand (kebutuhan), Dengan tetap mengoptimalkan desentralisasi, kordinasi antar sektor, kordinasi antar tingkat pemerintah, serta antar pemangku kepentinagan (stakeholder) Pada akhirnya, implikasi positif dari pelaksanaan PKH harus bisa dibuktikan secara empiris sehingga pengembangan PKH memiliki bukti nyata yang bisa dipertanggung jawabkan. Untuk itu, pelaksanaan PKH juga akan diikuti dengan program monitoring dan evaluasi yang optimal. Sedangkan Pendidikan adalah belajar. Belajar untuk menjadi insan yang berkualitas, dalam mengembangkan potensi dirinya untuk memiliki kekuatan dalam pengendalian diri, kepribadian, kecerdasan, ahklak mulia, serta ketrampilan yang dimiliki,dan tujuan Pendidikan yaitu untuk meningkatkan ketaqwaan terhadap Tuhan Yang Maha Esa, kecerdasan dan ketrampilan, mempertinggi budi pekerti, memperkuat kepribadian dan mempertebal semangat kebangsaan dan cinta tanah air, agar dapat menumbuhkan manusia-manusia pembangun yang dapat membangun dirinya sendiri serta bersama bertanggung jawab atas pembangunan bangsa. Sedangkan Partisipasi Pendidikan Anak dimulai dari anak usia dini (0-6 tahun) telah ada walaupun masih belum memadai. Data laporan UNICEF tentang Situasi Anak dan Perempuan tahun 2000 mencatat hanya $20 \%$ anak yang mengikuti pendidikan prasekolah dan terdapat 10-30\% anak mengalami hambatan perkembangan verbal, mental, dan psikomotorik. Rendahnya kualitas anak usia dini ini antara lain dipengaruhi oleh rendahnya mutu pendidikan dan pengetahuan keluarga dalam menstimulasi perkembangan anak.

\section{STUDI KEPUSTAKAAN}

Bank Dunia 1991, dalam Todaro (2006) menyatakan bahwa tujuan utama pembangunan adalah memperbaiki kualitas kehidupan. Sedangkan United Nations Development Programme UNDP 1991 dalam Todaro (2006) menyatakan bahwa cara terbaik untuk mewujudkan pembangunan adalah dengan meningkatkan kualitas manusia. Salah satu alat ukur untuk melihat aspek-aspek yang relevan dengan pembangunan manusia adalah melaui Human Development Index (HDI)yang dikenal dengan istilah IPM ( Indeks Pembangunan Manusia). IPM merupakan indeks komposit yang terdiri dari tiga komponen utama, yaitu kesehatan, 
pendidikan dan pendapatan yang diracik menjadi satu secara proporsional. Indikator kualitas SDM adalah Indeks Pembangunan Manusia (HDI= $H u$ man Development Indeks) (Depsos RI 2008).

\section{Indeks Pembangunan Manusia}

Indeks Pembangunan Manusia (IPM) mengukur capaian pembangunan manusia berbasis sejumlah komponen dasar kualitas hidup. Sebagai ukuran kualitas hidup, IPM dibangun melalui pendekatan tiga dimensi dasar. Dimensi tersebut mencakup umur panjang dan sehat; pengetahuan, dan kehidupan yang layak. Ketiga dimensi tersebut memiliki pengertian sangat luas karena terkait banyak faktor. Untuk mengukur dimensi kesehatan, digunakan angka harapan hidup waktu lahir. Selanjutnya untuk mengukur dimensi pengetahuan digunakan gabungan indikator angka melek huruf dan rata-rata lama sekolah. Adapun untuk mengukur dimensi hidup layak digunakan indikator kemampuan daya beli masyarakat terhadap sejumlah kebutuhan pokok yang dilihat dari ratarata besarnya pengeluaran per kapita sebagai pendekatan pendapatan yang mewakili capaian pembangunan untuk hidup layak.

Konsep Pembangunan Manusia yang dikembangkan oleh Perserikatan Bangsa-Bangsa (PBB), menetapkan peringkat kinerja pembangunan manusia pada skala 0,0 - 100 dengan katagori sebagai berikut : Tinggi : IPM lebih dari 80,0; Menengah Atas: IPM antara 66,0 - 79,9;Menengah Bawah : IPM antara 50,0 - 65,9;Rendah : IPM kurang dari 50,0.

\section{Kemiskinan}

Kemiskinan menurut BPS (2003), adalah ketidakmampuan dalam memenuhi kebutuhan dasar. Dengan kata lain kemiskinan dipandang sebagai ketidak mampuan dari sisi ekonomi untuk memenuhi kebutuhan makanan maupun non makanan yang bersifat mendasar. Garis kemiskinan makanan mengacu pada pengeluaran seseorang untuk memenuhi kebutuhan minimum makanannya sebanyak 2.100 kalori per orang.

World Bank (2002) menetapkan garis kemiskinan US \$ 2 per orang per hari. World Bank mendifinisikan kemiskinan merupakan kemampuan atau sumber daya yang dimiliki oleh rumah tangga atau individu untuk memenuhi kebutuhannya, berdasarkan aspek perbandingan pendapatan, pengeluaran, pendidikan, atau kelengkapan lain dari individu dengan beberapa batasan yang ditentukan, dan mereka yang berada di bawah batas yang ditentukan tersebut dikatakan sebagai miskin.

\section{Metode Penelitian}

Untuk menganalisis pengaruh dana bantuan PKH terhadap partisipasi pendidikan di Kecamatan Indrajaya Kabupaten Pidie maka digunakan model persamaan regresi linear sederhana. Persamaan regresi linear sederhana menurut Gujarati (2006 : 24) sebagai berikut:

$$
Y=\alpha+\beta X+e i
$$

Berdasarkan formulasi diatas, model analisis penelitian ini diformulasikan dalam bentuk Ln sebagai berikut:

$$
P P A=\alpha+\beta_{1} \operatorname{LnPKH}+e t
$$

Dimana :

PPA $=$ partisipasi pendidikan

$\alpha=$ konstanta

$\beta=$ Koefisien regresi

PKH = Jumlah bantuan PKH

Et $=$ Error term (variabel Pengganggu)

\section{Definisi Operasional}

Definisi operasional variabel merupakan batasan terhadap variabel-variabel yang digunakan dalam penelitian ini. Batasan-batasan tersebut antara lain :

1. Partisipasi pendidikan adalah tingkat pendidikan tertinggi si penerima dana bantuan PKH yang dilihat berdasarkan lamanya pendidikan.

2. Jumlah bantuan adalah dana yang dialokasikan oleh PKH kepada RTSM dalam satuan rupiah

3. Program keluarga harapan (pkh) adalah sebuah program jaminan sosial berupa bantuan tunai bersyarat dari pemerintah. program tersebut memiliki ketentuan serta hak dan kewajiban bagi penerima bantuan. program keluarga harapan sebagai upaya pemerintah untuk membantu rumah tangga sangat miskin dalam memperoleh akses pelayanan dasar yaitu pen- 
didikan dan kesehatan. dengan demikian diharapkan dapat mengurangi kemiskinan

\section{HASIL DAN PEMBAHASAN}

Penduduk Kabupaten Pidie berdasarkan proyeksi penduduk tahun 2015 sebanyak 418.882 jiwa yang terdiri atas 202.924 jiwa penduduk laki-laki dan 215.958 jiwa penduduk perempuan.Dibandingkan dengan proyeksi jumlah penduduk tahun 2014, penduduk Kabupaten Pidie mengalami pertumbuhan sebesar 2,02 persen dengan masing-masing persentase pertumbuhan penduduk laki-laki sebesar 2,30 persen dan penduduk perempuan sebesar 1,76 persen. Sementara itu besarnya angka rasio jenis kelamin tahun 2015 penduduk laki laki terhadap penduduk perempuan sebesar 93,96. Kepadatan penduduk di Kabupaten Pidie tahun 2015 mencapai 118 jiwa/km2 dengan rata-rata jumlah penduduk per rumah tangga 4 orang. Kepadatan Penduduk di 23 kecamatan cukup beragam dengan kepadatan penduduk tertinggi terletak di kecamatan Kota Sigli dengan kepadatan sebesar 2.145 jiwa/km2 dan terendah di Kecamatan Geumpang sebesar 11 jiwa/Km2. Sementara itu jumlah rumah tangga mengalami pertumbuhan sebesar 1,97 persen dari tahun 2014 . BPS Pidie (2016)

\section{Kemiskinan}

Garis Kemiskinan Kabupaten Pidie pada tahun 2015 sebesar Rp. 374.031. Jumlah penduduk miskin yang memiliki rata-rata pengeluaran perkapita perbulan dibawah Rp. 374.031,00 sebanyak 88.220 jiwa $(21,18 \%)$.

Selama tiga tahun terakhir, garis kemiskinan di kabupaten Pidie terus mengalami kenaikan. Garis kemiskinan sebesar Rp 361.707,- pada tahun 2013 terus meningkat menjadi Rp 374.031,pada tahun 2015. Artinya, pendapatan minimal yang harus dimiliki untuk dapat memenuhi kebutuhan hidup layak pada tahun 2015 adalah sebesar Rp 374.031,- per kapita per bulan.

\section{Angka Partisipasi Sekolah (APS)}

Angka Partisipasi Sekolah (APS) merupakan persentase penduduk yang masih bersekolah menurut kelompok usia tanpa memperhatikan jenjang pendidikan. APS dapat digunakan sebagai salah satu ukuran tercapainya tujuan pemerintah yakni kepastian penduduk untuk memperoleh pendidikan dasar dan menengah. Peningkatan APS dapat menjadi salah satu indikator adanya keberhasilan di bidang pendidikan. Semakin tinggi APS maka semakin besar jumlah penduduk yang mempunyai kesempatan mengenyam pendidikan, namun bukan berarti meningkatnya APS juga meningkatnya pemerataan kesempatan masyarakat untuk mengenyam pendidikan.

Secara keseluruhan, APS semakin menurun seiring dengan pertambahan usia. Selama tahun 2013 hingga 2015, APS pada kelompok umur 7-12 tahun baik laki-laki maupun perempuan mencapai 100 persen, artinya seluruh anak di Kabupaten Pidie pada kelompok umur tersebut telah mengenyam pendidikan. Sementara itu, masih terdapat 0,83 persen penduduk usia 13-15 tahun dan24,05 persen penduduk usia 16-18 tahun yang belum mengenyam pendidikan. Dilihat dari jenis kelamin, APS penduduk perempuan lebih tinggi dibanding laki-laki. Perbedaan tersebut semakin mencolok seiring dengan pertambahan usia. Pada kelompok usia 13-15 tahun, APS penduduk lakilaki dan perempuan masing-masing sebesar 98.31 persen dan 100 persen, sedangkan pada kelompok usia 16-18 tahun masingmasing sebesar 69.79 persen dan 81.96 persen.

\section{Angka Partisipasi Murni (APM)}

Angka Partisipasi Murni (APM) merupakan persentase jumlah anak yang sedang bersekolah pada jenjang pendidikan yang sesuai dengan usianya terhadap jumlah seluruh anak pada kelompok usia sekolah yang bersangkutan. Pada jenjang SD, angka APM sebesar 94,58 persen. Hal ini menggambarkan bahwa dari total penduduk usia 7-12 tahun, sekitar 94,58 persen di antaranya sedang duduk di bangku SD. Selanjutnya APM semakin menurun seiring dengan meningkatnya jenjang pendidikan. APM pada jenjang SMP dan SMA pada tahun 2015 masing-masing sebesar 88,32 persen dan 65,42 persen. Hal tersebut menunjukkan, semakin tinggi tingkat pendidikan, persentase penduduk usia sekolah yang bersekolah semakin berkurang, dengan kata lain masih terdapat banyak penduduk usia sekolah yang tidak melanjutkan sekolah ke jenjang yang lebih tinggi. 
Tabel 1

Angka Partisipasi Sekolah (APS) Usia 5-18 Tahun di Kabupaten Pidie Tahun 2015 (\%)

\begin{tabular}{lccc}
\hline Kelompok Umur & Jaki-laki & Perempuan & $\begin{array}{c}\text { Laki-laki+ } \\
\text { perempuan }\end{array}$ \\
\hline $5-6$ & 42,69 & 43.50 & 42,99 \\
\hline $7-12$ & 100 & 100 & 100 \\
\hline $13-15$ & 98.31 & 100 & 99.17 \\
\hline $16-18$ & 69.79 & 81.96 & 75.95 \\
\hline
\end{tabular}

Sumber: BPS Aceh 2016

Tabel 2

Angka Partisipasi Murni (APM) di Kabupaten Pidie Tahun 2015 (\%)

\begin{tabular}{lccc}
\hline Kelompok Umur & Laki-laki & $\begin{array}{c}\text { Jenis Kelamin } \\
\text { Perempuan }\end{array}$ & $\begin{array}{c}\text { Laki-laki+ } \\
\text { perempuan }\end{array}$ \\
\hline SD & 89.33 & 100 & 94.58 \\
\hline SMP & 78.60 & 97.68 & 88.32 \\
\hline SMA & 61.52 & 69.21 & 65.42 \\
\hline
\end{tabular}

Sumber: BPS Aceh 2016

Tabel 3

Hasil Perhitungan Regresi

\begin{tabular}{llll}
\hline \multicolumn{4}{c}{ Persamaan Regresi linear Sederhana } \\
\hline \multicolumn{1}{c}{ Variabel } & \multicolumn{1}{c}{ B } & P value & sig \\
\hline Konstanta & 12,177 & 76,278 & 0,000 \\
Bantuan PKH & 0,947 & 77,824 & 0,000 \\
\hline R-square $=0,968$ & F-hit $=60056$ & & \\
Koefiensi determinasi $=0,968$ & A $=5 \%$ & & \\
P- value $=0,000$ & & & \\
\hline
\end{tabular}

Sumber: Hasil Pengolahan Data, 2015 (data diolah) 
Selanjutnya, jika dilihat dari jenis kelamin, APM penduduk perempuan lebih tinggi dibanding penduduk laki-laki pada semua jenjang, seperti tercantum pada Tabel 2 berikut.

\section{Hasil Estimasi}

Analisis Pengaruh Bantuan Program Keluarga Harapan (PKH) Terhadap Partisipasi Pendidikan di Kecamatan Indrajaya Kabupaten Pidie

Untuk mengetahui pengaruh bantuan program keluarga harapan (PKH) terhadap Partisipasi Pendidikan di Kecamatan Indrajaya Kabupaten Pidie maka dilakukan pengujian dengan menggunakan alat ukur regressi liniear sederhana. Hasil penelitian ini dapat dilihat pada Tabel 1 .

Berdasarkan Tabel 3 diatas diketahui bahwa hasil Dari penelitian diperoleh persamaan akhir estimator yaitu PPA $=12,77+0,947$ PKH. Persamaan tersebut mengandung pengertian bahwa:

-Konstanta sebesar 12,177 artinya apabila variabel bantuan $\mathrm{PKH}$ dianggap konstan maka partisipasi pendidikan di Kecamatan Indrajaya Kabupaten Pidie sebesar 12,177 persen. Apabila variabel bantuan $\mathrm{PKH}$ mengalami perubahan sebesar 1 persen maka akan berpengaruh terhadap meningkatnya partisipasi pendidikan di Kecamatan Indrajaya Kabupaten Pidie sebesar 0,947 persen dengan asumsi variabel lainnya dianggap tetap.

Koefisien determinan $\left(\mathrm{R}^{2}\right)$ bernilai 0,968 menunjukkan bahwa bantuan PKH mampu menjelaskan/mempengaruhi partisipasi pendidikan di Kecamatan Indrajaya Kabupaten Pidie sebesar 96,8 persen dan sisanya sebesar 3,2 persen di pengaruhi oleh variabel lainnya diluar model penelitian ini.

\section{KESIMPULAN}

Dari hasil penelitian yang telah dilakukan maka dapat di ambil kesimpulan yaitu :

1. Bantuan PKH mampu menjelaskan atau mempengaruhi partisipasi pendidikan anak - anak RTSM di Kecamatan Indrajaya Kabupaten Pidie mencapai 96,8 persen dan sisanya sebesar 3,2 persen di pengaruhi oleh variabel lainnya diluar model penelitian ini.

2. Hasil pembuktian hipotesis baik secara parsial maupun simultan menunjukkan bahwa bantuan PKH berpengaruh signifikan terhadap partisipasi pendidikan anak - anak RTSM di Kecamatan Indrajaya Kabupaten Pidie.

\section{SARAN}

Berdasarkan hasil pembahasan dan kesimpulan terhadap penelitian ini maka saran-saran yang dapat diberikan adalah sebagai berikut :

1. Diharapkan juga kepada pemerintah supaya Program Bantuan PKH itu dapat diberikan kepada anak-anak keluarga RTSM yang mau serta sedang menempuh pendidikan pada tingkat SLTA.

2. Diharapkan kepada lembaga yang memberi bantuan PKH hendaknya tepat sasaran dan benar-benar ditujukan untuk meningkatkan pendidikan anak. Hal ini penting, karena bantuan tersebut hanya bersifat sementara dan lebih terfokus untuk memuskan mata ranta kemiskinan setelah itu tidak diberikan lagi.

3. Masyarakat yang mendapatkan bantuan PKH sebaiknya berkonsentrasi penuh untuk mengembangkan pendidikan si anak sampai selesai minimal tingkat SLTP. 


\section{REFERENSI}

Aceh dalam angka 2016, BPS Provinsi Aceh.

Arsyad. Lincolin, 2004. Pengantar Perencanaan dan Pembangunan Ekonomi daerah. Yogyakarta: BPFE.

BPS 2012 Indek Pembangunan Manusia . Jakarta

BPS 2009. Profil Kemiskinan Di Indonesia Maret 2009. Jakarta

BPS 2015 Pidie Dalam Angka. BPS Pidie.

Gujarati (2006) Ekonometrika, Ghalia,Jakarta

Direktorat Jaminan Kesejahteraan Sosial Direktorat Jenderal Bantuan dan Jaminan Sosial Departemen Sosial RI. 2008. Pedoman Umum PKH 2008.

Direktorat Jaminan Kesejahteraan Sosial Direktorat Jenderal Bantuan dan Jaminan Sosial Departemen Sosial RI. 2008. Pedoman Umum PKH 2013.

Direktorat Jaminan Kesejahteraan Sosial Direktorat Jenderal Bantuan dan Jaminan Sosial Departemen Sosial RI. 2008. Pedoman Operasional Kelembagaan PKH.

Todaro, M. dan Smith. S. 2004. Pembangunan Ekonomi di Dunia Ketiga, Edisi Kedelapan, Jakarta: Erlangga.

UNDP, BPS dan Bappenas (2001). Laporan Pembangunan Manusia, Demokrasi dan Pembangunan Manusia Indonesia, Jakarta 2001.

World Bank. 2002. Indikator kemiskinan 2002, Jakarta. 
